\section{Congener specific distribution and health risk assessment of polychlorinated biphenyls in urban soils}

\author{
Bhupander Kumar, Sanjay Kumar, \\ Chandra Shekhar Sharma \\ National Reference Trace Organics \\ Laboratory, Central Pollution Control \\ Board, East Arjun Nagar, Delhi, India
}

\section{Abstract}

Polychlorinated biphenyls (PCBs) were primarily used in transformers and capacitors, lubricants, flame retardants, plasticizers, paint, carbonless papers, etc. These are capable of long-range atmospheric transport and have been designated as persistent organic pollutants by the Stockholm Convention. Due to their characteristic properties, $\mathrm{PCBs}$ are found worldwide in all environmental matrices (including human) and biota. Soils are usually considered to be the source as well as sink for environmental pollutants, with cumulative effects of long-range atmospheric transport and local sources. Around the world, comparatively higher concentrations of PCBs have been reported in urban soils than suburban or rural soils. Higher amount of PCBs in urban soils may cause toxicological health risks to urban residents through ingestion, inhalation and skin contact. This paper presents the PCB distribution in soils from Delhi, India, and exposure risk estimates for human health through soil ingestion. The concentration of $\sum$ PCBs ranged between 1.08-100.67 $\mathrm{ng} \mathrm{g}^{-1}$ (mean $21.16 \mathrm{ng} \mathrm{g}^{-1} \pm 5.24 \mathrm{ng} \mathrm{g}^{-1}$ ), which was much lower than the Canadian soil quality guideline value of $1.3 \mathrm{mg} / \mathrm{kg}$ or $1300 \mathrm{ng} \mathrm{g}^{-1}$. Human health risk estimates through the soil ingestion pathway were made in terms of lifetime average daily dose (LADD), incremental lifetime cancer risks and non-carcinogenic hazard quotient (HQ). The LADD for Delhi adults and children was $3.02 \times 10^{-8} \mathrm{mg} \mathrm{kg}^{-1} \mathrm{~d}^{-1}$ and $1.57 \times 10^{-7} \mathrm{mg} \mathrm{kg}^{-1} \mathrm{~d}^{-1}$, respectively, which corresponds to toxic equivalent quotients (TEQ) intake of $0.105 \mathrm{pg}^{2}$ TEQ $\mathrm{kg}^{-1} \mathrm{~d}^{-1}(0.735 \mathrm{pg}$ TEQ $\mathrm{kg}^{-1}$ week ${ }^{-1}$ ) and $0.543 \mathrm{pg}$ TEQ $\mathrm{kg}^{-1} \mathrm{~d}^{-1}$ (3.801 $\mathrm{pg}^{\mathrm{TEQ}} \mathrm{kg}^{-1}$ week $^{-1}$ ), respectively. The estimated LADD for Delhi residents was lower than the acceptable intake values recommended by the World Health Organization (1 pg TEQ $\mathrm{kg}^{-1} \mathrm{~d}^{-1}$ ), the European Commission (14 pg TEQ $\mathrm{kg}^{-1}$ week $\left.^{-1}\right)$ and by the Japanese government (4 pg TEQ $\mathrm{kg}^{-1} \mathrm{~d}^{-1}$ ). The probability of cancer risk ranges from $6.04 \times 10^{-8}\left(\sum \mathrm{PCBs}\right)$ to $1.57 \times 10^{-5}$ ( $\sum$ TEQ $)$ and $3.13 \times 10^{-7}$ ( $\sum$ PCBs) to $8.15 \times 10^{-5}$ ( $\sum$ TEQ) for adults and children, respectively, and was within acceptable ranges of $10^{-6}$ to $10^{-4}$. The non-carcinogenic risk in terms of health HQ was 0.105 and 0.330 for adults and children, respectively, which was lower than the acceptable limit of 1 . The study found lower concentrations of PCBs than guideline values and low health risk estimates through the soil ingestion pathway within acceptable levels, indicating a minimum risk for Delhi residents.

\section{Introduction}

Polychlorinated biphenyls (PCBs) are a group of 209 congeners and have been designated as persistent organic pollutants by the Stockholm Convention. PCBs were primarily used in transformers and capacitors as dielectric and coolant fluids and in lubricants, flame retardants, plasticizers, paint, etc. ${ }^{1}$ Even though the production has been banned since the 1970s and usage of these contaminants are restricted in many countries, PCBs continue to be detected in environmental samples from around the world. ${ }^{2}$

PCBs are toxic, bioaccumulative, and can undergo long-range atmospheric transport world-wide to regions such as the Arctic, Antarctic and high altitude regions of Mount Everest. $^{3-5}$ PCBs are characterized by high thermal and chemical stabilities, low vapor pressures, high dielectric constants, hydrophobicity, high lipophilicity, and extreme resistant to degradation. Because of these characteristics, PCBs accumulate in soil, sediments and biota. ${ }^{6}$

Soils of urban areas are usually known as the source as well as sink for environmental pollutants, where cumulative effects of longrange atmospheric transport and local sources are the important factors. ${ }^{7,8}$ As a result, comparatively higher concentrations of PCBs have been reported in urban soils than suburban or rural soils. ${ }^{9,10}$ Humans are exposed to PCBs mainly through the consumption of contaminated food, and occupational exposure to PCBs occurs mainly via the inhalation and dermal routes. Higher amount of PCBs in soils, especially dioxin-like PCBs (dl-PCBs), may cause toxicological health risks to urban residents through ingestion, inhalation and skin contact. ${ }^{11}$ In earlier studies, the potential risk to human health from PCBs in urban soils has been reported. ${ }^{12-13}$ Therefore, more attention should be given to the status of PCBs in urban soils and the possible risk to human and environmental health.

In earlier investigations, occurrence of PCBs had been reported in environmental and biological samples from India. ${ }^{14-20}$ In this study we quantified the levels of PCBs and their risk estimates in urban soils from the Delhi metro-
Correspondence: Bhupander Kumar, National Reference Trace Organics Laboratory, Central Pollution Control Board, East Arjun Nagar Delhi110032 India.

E-mail: bhupander_kumar@yahoo.com

Key words: polychlorinated biphenyls, urban soil, risk assessment, lifetime average daily dose, health hazard quotient.

Acknowledgments: the authors express their sincere gratitude to the Chairman and Member Secretary of the Central Pollution Control Board for encouragement to conduct the study on POPs. Authors also thank Mr. SK Singh and Ms. Richa Gaur for their help during sample processing and analysis.

Contributions: the authors contributed equally.

Conflict of interests: the authors declare no potential conflict of interests.

Received for publication: 11 June 2012.

Revision received: 27 August 2012.

Accepted for publication: 28 August 2012.

This work is licensed under a Creative Commons Attribution NonCommercial 3.0 License (CC BYNC 3.0).

(C) Copyright B. Kumar et al., 2012

Licensee PAGEPress, Italy

Journal of Xenobiotics 2012; 2:e10

doi:10.4081/xeno.2012.e10

politan area. This is probably the first study to present the 28 PCB-congener levels, including dioxin-like PCBs, in soils from Delhi, and may provide the base-line statistical data needed for health effect assessments. For this purpose, PCBs were extracted from soils using accelerated solvent extraction (ASE) and quantified.

\section{Materials and Methods}

\section{Study area and sampling}

The sampling area was the national capital territory (NCT), Delhi, which is the capital of India with a population of 1.67 million. The total area of NCT, Delhi, is approximately 1483 $\mathrm{km}^{2}$ and is located in northern India between $28^{\circ} 24^{\prime} 17^{\prime \prime} \mathrm{N}$ to $28^{\circ} 53^{\prime} 00^{\prime \prime} \mathrm{N}$ and between $76^{\circ} 50^{\prime} 24^{\prime \prime} \mathrm{E}$ to $77^{\circ} 20^{\prime} 37^{\prime \prime} \mathrm{E}$. Average annual rainfall is $714 \mathrm{~mm}$. The climate in Delhi is hot and humid. During summer, temperatures rise up to $40-45^{\circ} \mathrm{C}$ and in winters temperatures fall to $4-5^{\circ} \mathrm{C} .^{21}$

The soil samples were collected during June 2011 from 14 urban locations on streets and roads near residential areas in Delhi. Approximately 1/2 kg of soil sample was collect- 
ed from each sampling location, and after removing pebbles, sticks and leaves the sample was mixed thoroughly until homogenized. One part was then transferred to clean, widemouthed amber glass containers that were then labeled. After collection, samples were transported to the laboratory and kept at $4^{\circ} \mathrm{C}$ until analysis.

\section{Chemicals and solvents}

Chemicals (sodium sulfate, potassium hydroxide and sulfuric acid) and solvents (high performance liquid chromatography grade acetone, hexane and dichloromethane) were purchased from Merck India. Pre-cleaned silica gel 60 (0.063-0.100 mm) was obtained from Supelco (Sigma-Aldrich Corp., St. Louis, M0, USA) and used as adsorbent in column chromatography. Prior to use, anhydrous sodium sulfate was cleaned separately with methanol, dichloromethane and acetone in Soxhlet extractor for $8 \mathrm{~h}$ each, and stored in air-tight conditions at $130^{\circ} \mathrm{C}$. Reference standard solutions of PCBs were purchased from Dr. Ehrenstorfer (Dr. Ehrenstorfer $\mathrm{GmbH}$, Augsburg, Germany) and used for the instrument calibration and quantification.

\section{Sample extraction, clean up and analysis}

Sample extraction and clean up was carried out according to validated methods..$^{22}$ Briefly, a homogenized $20 \mathrm{~g}$ sample was dried by mixing with diatomaceous earth (ASE prep DE, Dionex Corp., Sunnyvale, CA, USA) until a free-flowing powder was obtained. The extraction was carried out with accelerated solvent extractor (ASE-350, Dionex Corp.) using acetone/hexane $(\mathrm{v} / \mathrm{v}, 1: 1)$ solvent mixture in two cycles with 5 min static time. The ASE was operated at $1500 \mathrm{psi}$ and the oven temperature was maintained at $100^{\circ} \mathrm{C}$. The extracts were concentrated to $2.0 \mathrm{~mL}$ using a rotatory vacuum evaporator (Eyela, Tokyo, Japan). Multilayered silica gel column chromatography on a tri-functional column with neutral, basic and acidic silica was performed to remove interfering organic and polar compounds. Details of methodology for clean up and instrumental analysis are reported elsewhere. ${ }^{20}$

\section{Quality control analysis}

Appropriate quality assurance quality control analysis was performed, including analysis of procedural blanks (analyzed concentrations $<$ method detection limit, MDL), random duplicate samples (standard deviation, $\mathrm{SD}<5 \%$ ), calibration standard verification $(\mathrm{SD}<15 \%)$ and matrix spike recovery $(100 \pm 20 \%) .^{20}$ PCB congeners were identified in the sample extract by comparing the accurate retention time from the standard mixture and quantified using the response factors from multi-level calibration curves of the standards ( $r^{2}$ value 0.999$)$.

A signal to noise ratio of $3: 1$ was used to calculate instrument detection limits by using a valid quantifiable peak. Each sample was analyzed in duplicate and the average was used in calculations. Method detection limits were established by processing 8 aliquots of a sample spiked with a quantity sufficient to produce a detectable response $(\mathrm{s} / \mathrm{n}>3)$ and multiplying the standard deviation by the $t_{\text {students }}$ value (3.0 for 8 replicates). For statistical calculations the non-detect values of PCB congeners have been reported as $<0.01 \mathrm{ng} \mathrm{g}^{-1}$ (MDL of all 28 individ-

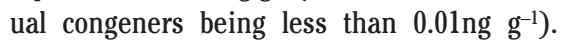
Furthermore, it may be noted that our laboratory is ISO 17025 accredited and had been participating in proficiency testing exercises conducted by international agencies, including the Centre d'expertise en analyse environnementale du Québec, and performance scores were satisfactory for PCBs.

Toxic equivalent quotients (TEQ) of each congener were calculated by multiplying the concentration of individual dl-PCB congener with the toxic equivalent factors (TEFs) ${ }^{11}$ with reference to 2,3,7,8-tetrachloro dibenzo- $p$ dioxin (TCDD) and reported as pg $\mathrm{WHO}_{2005^{-}}$ TEQ $\mathrm{g}^{-1}$ dry-weight (dw).

\section{Health risk assessment for poly- chlorinated biphenyls exposure}

In this study, assessment of human health risk is discussed as the calculated estimates of the upper-bound excess probabilistic lifetime cancer risk and non-carcinogenic hazards. Hazard is the exact measure of the magnitude of exposure potential or a quantifiable potential for developing non-carcinogenic health effects after averaged exposure period. Risk is the probability of cancer development in a lifetime after a uniform exposure. ${ }^{23}$ We estimated the human exposure to PCBs through soil ingestion and the consequent health risk by using equations presented by United States Environmental Protection Agency. ${ }^{24-26}$ For this purpose, the LADD (lifetime average daily dose), non-cancer risk HQ (hazard quotient) and probabilistic incremental lifetime cancer risks (ILCR) were calculated. LADD is an amount a person takes in as a result of exposure to a chemical in contaminated air, water, soil or food. The input parameters used in the health risk estimation for PCBs are given in Table 1. The equations used for estimating LADD, HQ (non-cancer risk) and probable cancer risk were as follows:

\section{LADD $\left(\mathrm{mg} \mathrm{kg}^{-1}\right.$ day $\left.^{-1}\right)=($ Cs x IR x F x EF x $\mathrm{ED}) /(\mathrm{BW} x \mathrm{LT})$ \\ $\mathrm{HQ}=\mathrm{LADD} / \mathrm{RfD}$ \\ ILCR=LADD $\mathrm{x}$ cancer slope factor oral}

where:

Cs is the total PCBs concentration in soil ( $\mu$ g $\mathrm{kg}^{-1}$ );

IR is the soil ingestion rate $\left(\mathrm{mg} \mathrm{day}^{-1}\right)$;

$\mathrm{F}$ is the unit conversion factor $\left(10^{-9}\right)$;

$\mathrm{EF}$ is exposure frequency (days/year);

ED is the exposure duration (year);

BW is the body weight $(\mathrm{kg})$;

LT is the lifetime which is equal to exposure duration $x 365$ days (days);

$\mathrm{RfD}$ is the reference dose for individual dl-PCB congener ( $\mathrm{mg} \mathrm{kg}^{-1}$ day $\left.^{-1}\right)$.

An RfD is a daily intake rate that is estimated to cause no adverse health effects over a specific exposure duration. Non-carcinogenic risks (HQ) were assessed by comparing exposure with RfD of each dl-PCB and the total was reported for each sampling location. Cancer risk for dioxin-TEQ was calculated for each of the $12 \mathrm{dl}-\mathrm{PCB}$ congeners from LADD by multiplying slope factor for dioxin $\left(150,000 / \mathrm{mg} \mathrm{kg}^{-1}\right.$ day $^{-1}$ ) and the total was reported. Cancer risk for non-dl-PCBs was calculated from LADD of 28 PCBs by multiplying the upper bound cancer slope factor $\left(2 / \mathrm{mg} \mathrm{kg}^{-1} \mathrm{~d}^{-1}\right)$. The upper

Table 1. Summary of input parameters used in calculations for health risk assessment.

\begin{tabular}{llll} 
Symbol & Parameter & Unit & Point estimate \\
Cs & PCB concentration & $\mu \mathrm{kg}^{-1}$ & Data from this study \\
$\mathrm{C}_{\text {TEQ }}$ & TEQ concentration & $\mu \mathrm{g} \mathrm{TEQ} \mathrm{kg}^{-1}$ & Data from this study \\
\hline $\mathrm{IR}$ & Soil ingestion rate & $\mathrm{mg} \mathrm{day}^{-1}$ & 100 (adults), 200 (children) \\
EF & Exposure frequency & Days/year & 365 days \\
\hline ED & Exposure duration & Years & 70 (adults), 12 (children) \\
BW & Body weight & Kg & 70 (adults), 27 (children) \\
\hline LT & Life time & Days & $70 \times 365=25,550$ (adults) \\
& & & $12 \times 365=4382$ (children) \\
CSF & Cancer slope factor & Per mg kg-1 day ${ }^{-1}$ & Dioxin-TEQ: 150,000 \\
& & & Non-dl-PCBs: 2 (upper bound) \\
\hline F & Unit conversion factor & - & $10^{-6}$ \\
\hline Cs, concentration in soil; dl-PCBs, dioxin-like polychlorinated biphenyls; TEQ, toxic equivalent quantities.
\end{tabular}


bound slope factor is used for those exposure pathways for which environmental processes are likely to increase health risk, such as exposure from consumption of foods, sediment or soil ingestion, and dust or aerosol inhalation.

\section{Results}

\section{Polychlorinated biphenyls concen- trations in soil}

The concentrations of $\sum$ PCBs and individual 28 congeners in urban soils from Delhi, India, are presented in Table 2 . The observed levels of total PCBs ranged between 1.08- $100.67 \mathrm{ng} \mathrm{g}^{-1}$ (dw) with the mean and median of $21.16 \mathrm{ng} \mathrm{g}^{-1}$ and $10.16 \mathrm{ng} \mathrm{g}^{-1}\left( \pm 5.24 \mathrm{ng} \mathrm{g}^{-1}\right)$, respectively, which is at par with those of other cities around the world. The most common congener numbers among studied PCBs were CB-44, CB-52 and CB-138. The concentration range of $12 \mathrm{dl}-$ PCBs was 0.10-22.57 $\mathrm{ng} \mathrm{g}^{-1}$ (mean $5.33 \mathrm{ng}$ $\mathrm{g}^{-1} \pm 0.55 \mathrm{ng} \mathrm{g}^{-1}$, median $2.00 \mathrm{ng} \mathrm{g}^{-1} \pm 0.55 \mathrm{ng} \mathrm{g}^{-1}$ ) and accounted for approximately $25 \%$ of total PCBs. TEQ of 12 dl-PCBs, calculated using WHO ${ }_{2005}$-TEFs, ranged from less than 1 to $387 \mathrm{pg}$-TEQ $\mathrm{g}^{-1}$ (mean $73 \pm 28$ pg-TEQ g $^{-1}$ ). Non-ortho-PCBs (CB-77, CB-81, CB-126 and CB-169) were the sole contributors and accounted for over $99 \%$ of total TEQ (Table 3). Tetrachorinated, pentachlorinated and hexachlorinated biphenyls were the dominant homologues groups of PCBs (Table 4, Figure 1).

\section{Health risk assessment}

Adults and children may be exposed to contaminants in soil and may also take chemicals from soil through different intake pathways, such as ingestion, inhalation and dermal contact. Figure 2 shows average of $\Sigma$ PCBs in urban soil at different locations in Delhi, India. The calculated average daily intake of PCBs through soil ingestion by adults and children in Delhi was $3.02 \times 10^{-8} \mathrm{mg} \mathrm{kg}^{-1} \mathrm{~d}^{-1}$ and $1.57 \times 10^{-7} \mathrm{mg} \mathrm{kg}^{-1} \mathrm{~d}^{-1}$, respectively (Table 5 ), for a soil PCB concentration of $21.2 \mu \mathrm{g} \mathrm{kg}^{-1}$. With respect to RfD, the average LADD for adults and children was less than $1 \%$ and less than $5 \%$, respectively, of the RfD. The calculated value of TCDD substituted WHO-TEQ daily intake for adults and children was $1.05 \times 10^{-10}$ mg TEQ $\mathrm{kg}^{-1} \mathrm{~d}^{-1}$ and $5.43 \times 10^{-10} \mathrm{mg}$ TEQ $\mathrm{kg}^{-1} \mathrm{~d}^{-1}$, respectively, when soil TEQ was $0.073 \mu \mathrm{g} \mathrm{kg}^{-1}$ (Table 5). The calculated probability cancer risk estimate for PCB exposure from ingestion of soil was $6.04 \times 10^{-8}$ ( $\left.\sum \mathrm{PCBs}\right)$ to $1.57 \times 10^{-5}$ ( $\mathrm{TTE}$ ) and $3.13 \times 10^{-7}$ ( $\sum \mathrm{PCBs}$ ) to $8.15 \times 10^{-5}$ ( $\sum$ TEQ) for Delhi adults and children, respectively (Table 5). The quantified non-carcinogenic HQ for soil ingestion pathway of PCBs was 0.105 and 0.330 for Delhi adults and children, respectively (Figure 3).
Table 2. Polychlorinated biphenyl congener concentrations (ng/g dw) in urban soils from Delhi, India.

\begin{tabular}{|c|c|c|c|c|c|}
\hline Congeners & Range & Mean & Median & $\mathrm{SE}^{*}$ & $\%$ \\
\hline PCB-18 & $0.17-4.31$ & 1.02 & 0.51 & 0.18 & 3.8 \\
\hline PCB-37 & $0.21-7.07$ & 1.38 & 0.76 & 0.27 & 5.1 \\
\hline PCB-44 & $0.24-15.60$ & 2.78 & 1.13 & 0.61 & 11.2 \\
\hline PCB-49 & $0.22-10.20$ & 1.96 & 1.01 & 0.36 & 7.9 \\
\hline PCB-52 & $0.18-11.2$ & 2.56 & 1.00 & 0.52 & 11.3 \\
\hline PCB-70 & $0.08-6.30$ & 1.30 & 0.43 & 0.28 & 5.3 \\
\hline PCB-74 & $0.16-5.11$ & 1.35 & 0.59 & 0.23 & 5.5 \\
\hline PCB-119 & $<0.01$ & & & & \\
\hline PCB-128 & $0.09-2.62$ & 0.55 & 0.34 & 0.10 & 2.2 \\
\hline PCB-138 & $0.06-12.80$ & 2.54 & 1.02 & 0.55 & 11.1 \\
\hline PCB-151 & $0.12-2.66$ & 0.70 & 0.21 & 0.12 & 1.9 \\
\hline PCB-168 & $0.08-9.68$ & 1.61 & 0.49 & 0.37 & 7.6 \\
\hline PCB-170 & $<0.01$ & & & & \\
\hline PCB-177 & $0.09-0.76$ & 0.36 & 0.22 & 0.04 & 1.1 \\
\hline PCB-187 & $0.11-0.70$ & 0.41 & 0.41 & 0.06 & 0.3 \\
\hline PCB -207 & $0.09-0.55$ & 0.32 & 0.32 & 0.03 & 0.5 \\
\hline$\sum$ PCBs & $0.77-78.93$ & 15.83 & 7.30 & 3.29 & 74.8 \\
\hline dl-PCB-77 & $0.11-2.25$ & 0.63 & 0.41 & 0.10 & 1.5 \\
\hline dl-PCB-81 & $<0.01$ & 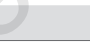 & & & \\
\hline dl-PCB-126 & $0.07-2.63$ & 0.62 & 0.40 & 0.10 & 2.3 \\
\hline dl-PCB-169 & $0.13-4.12$ & 1.14 & 0.61 & 0.18 & 3.9 \\
\hline dl-PCB-105 & $0.25-8.5$ & 1.60 & 1.06 & 0.32 & 6.0 \\
\hline dl-PCB-114 & $0.22-3.55$ & 1.79 & 1.79 & 0.30 & 1.2 \\
\hline dl-PCB-118 & $0.10-1.65$ & 0.72 & 0.54 & 0.07 & 3.2 \\
\hline dl-PCB-123 & $<0.01$ & & & & \\
\hline dl-PCB-156 & $0.08-2.87$ & 0.78 & 0.20 & 0.15 & 1.8 \\
\hline dl-PCB-157 & $0.10-2.70$ & 0.93 & 0.74 & 0.14 & 1.6 \\
\hline dl-PCB-167 & $0.07-3.41$ & 0.80 & 0.30 & 0.17 & 2.7 \\
\hline dl-PCB-189 & $0.09-1.30$ & 0.41 & 0.32 & 0.05 & 1.1 \\
\hline$\sum$ dl-PCBs & $0.10-22.57$ & 5.33 & 2.00 & 0.55 & 25.2 \\
\hline Total $_{(\mathrm{PCBs}+\mathrm{dl}-\mathrm{PCBs})}$ & $1.08-100.67$ & 21.16 & 10.16 & 5.24 & 100 \\
\hline
\end{tabular}

$<0.01$, below detection limit; *SE, standard error $(\mathrm{SD} / \sqrt{ } \mathrm{n})$; dl-PCBs, dioxin-like polychlorinated biphenyls.

Table 3. Toxic equivalent quotients of dioxin-like polychlorinated biphenyl congeners in urban soils from Delhi, India.

\begin{tabular}{lcccc} 
dl-PCBs & Range & $\begin{array}{c}\left(\mathrm{pg} \mathrm{WHO}_{2005}-\mathrm{TEQ}_{\mathrm{g}}^{-1}\right) \\
\text { Mean }\end{array}$ & SE & $\%$ \\
Non ortho-PCBs & $<1-387$ & 73 & 28 & 99 \\
Mono ortho-PCBs & $<1$ & $<1$ & $<1$ & $<1$ \\
\hline$\sum$ dl-PCBs & $<1-387$ & 73 & 28 & 100 \\
\hline
\end{tabular}

SE, standard error; dl-PCBs, dioxin-like polychlorinated biphenyls; TEQ, toxic equivalent quotients.

Table 4. Polychlorinated biphenyl homologues (3-7 CB) in urban soils from Delhi, India (ng/g dw).

\begin{tabular}{lccccc}
\hline Homolog & Tri-CB & Tetra-CB & Penta-CB & Hexa-CB & Hepta-CB \\
Mean & 1.88 & 9.03 & 4.94 & 4.52 & 0.53 \\
Median & 1.05 & 3.55 & 1.63 & 1.31 & 0.22 \\
\hline Range & $<0.01-11.38$ & $0.23-48.93$ & $<0.01-31.30$ & $0.06-24.31$ & $<0.01-2.05$ \\
\% of $\sum$ PCBs & 10.3 & 49.0 & 17.3 & 18.8 & 4.7 \\
\hline
\end{tabular}

PCBs, polychlorinated biphenyls. 
Table 5. Calculated polychlorinated biphenyl exposure from urban soil and risk for adults and children.

\begin{tabular}{lccccc} 
Soil ingestion & $\begin{array}{c}\text { Concentration } \\
(\text { ug/kg) }\end{array}$ & LADD & Risk & LADD & Risk \\
Dioxin-TEQ & 0.073 & $1.05 \times 10^{-10}$ & $1.57 \times 10^{-5}$ & $5.43 \times 10^{-10}$ & $8.15 \times 10^{-5}$ \\
Non-dl-PCBs & 21.2 & $3.02 \times 10^{-8}$ & $6.04 \times 10^{-8}$ & $1.57 \times 10^{-7}$ & $3.13 \times 10^{-7}$ \\
\hline
\end{tabular}

LADD, lifetime average daily dose (mg/kg bw/d); dl-PCB, dioxin-like polychlorinated biphenyls; TEQ, toxic equivalent quotients.

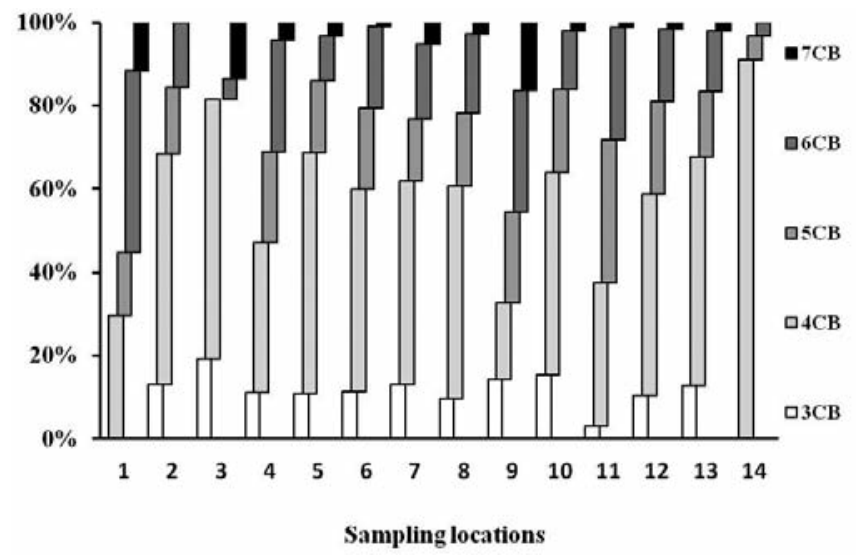

Figure 1. Polychlorinated biphenyl homologs in soil at different locations in Delhi, India.

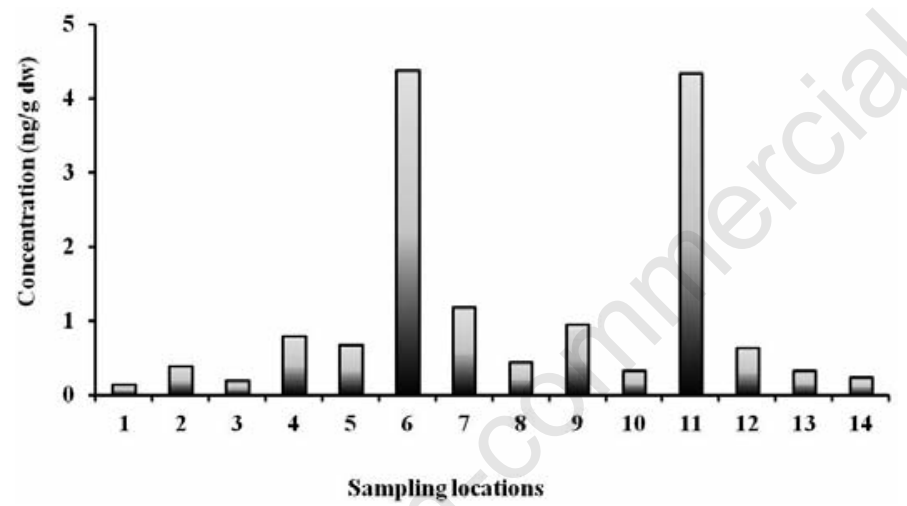

Figure 2. Average of $\sum$ polychlorinated biphenyls in urban soil at different locations in Delhi, India.

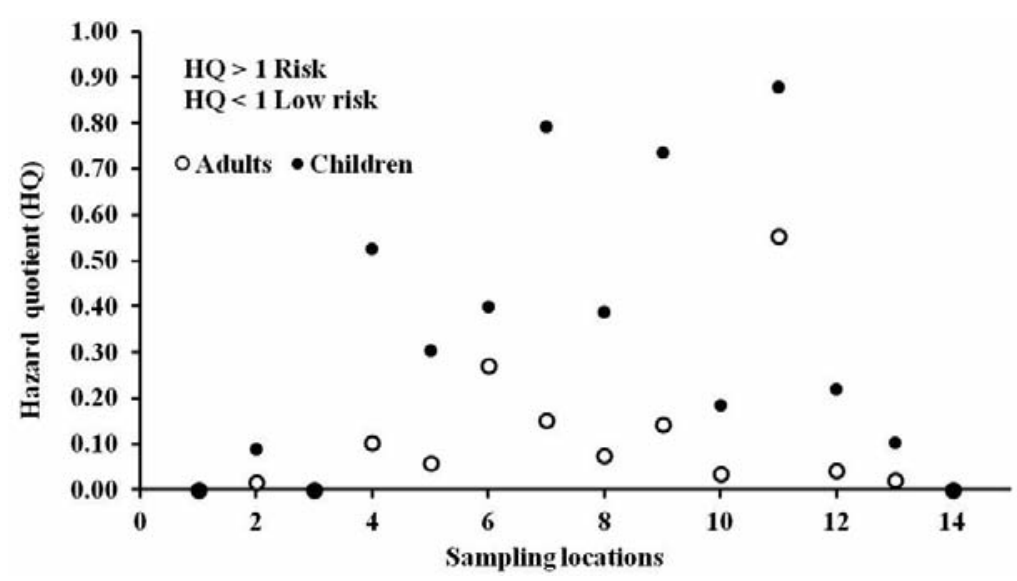

Figure 3. Health risk hazards of polychlorinated biphenyls for adults and children through soil ingestion.

\section{Discussion}

\section{Concentrations and possible sources}

The PCBs contamination levels in soils from Delhi were much lower than soil quality guidelines $\left(1.3 \mathrm{mg} / \mathrm{kg}\right.$ or $\left.1300 \mathrm{ng} \mathrm{g}^{-1}\right){ }^{27}$ The results of this study were similar to observations reported for urban soils from Kathmandu, ${ }^{7}$ urban soils of Beijing ${ }^{28}$ and from Tibet. ${ }^{29}$ However, the concentrations of PCBs in Delhi soils were lower than those of Vietnam, ${ }^{30}$ Switzerland, ${ }^{31}$ Romania, ${ }^{32}$ China ${ }^{33}$ San Felipe, Nuevo Mercurio, Zacatecas, Mexico, ${ }^{34}$ Moscow $^{35}$ and Guangdong Province, South China, ${ }^{36}$ but higher than PCBs reported in soils from Turkey. ${ }^{37}$

The PCB patterns show that the low molecular weighted PCBs were major contributors (60\%) compared to high molecular weight PCBs (with 40\%). Low molecular weight PCBs were primarily used in electrical equipments while high molecular weight PCBs were mainly used as additives in various applications. ${ }^{38}$ PCBs had never been produced in India, but are used in industrial applications. ${ }^{39}$ Possible sources of PCBs releases in the study area may be from electronic and electrical waste recycling and industrial emission depositions. During the burning of different mixtures of waste content, garden waste, paper, plastics, PVC (polyvinyl chloride) and painted wood may produce relatively large amounts of dioxin likePCBs. ${ }^{40-42}$

\section{Risk estimates}

To ensure public health safety, a tolerable daily intake (TDI) has been set by international agencies. The TDI is the amount of intake per $\mathrm{kg}$ of body weight per day of a chemical substance suspected of having adverse health effects when absorbed into the body over a long period of time. The joint FAO/WHO Expert Committee on Food Additives ${ }^{43}$ recommended a TDI of $1.0 \mathrm{pg}$ TEQ $\mathrm{kg}^{-1} \mathrm{~d}^{-1}$ for acute, subchronic and chronic exposures to dioxins. The European Commission ${ }^{44}$ established an acceptable weekly intake of $14 \mathrm{pg}$ WHO-TEQ/kg body weight for dioxins and $12 \mathrm{pg}$ dioxin-like PCBs. The Japanese government ${ }^{45}$ established the TDI of dioxins at $4 \mathrm{pg}^{-T E Q} \mathrm{~kg}^{-1} \mathrm{~d}^{-1}$.

The observed LADD of TEQ intake for adults $\left(1.05 \times 10^{-10} \mathrm{mg}\right.$ TEQ $\left.\mathrm{kg}^{-1} \mathrm{~d}^{-1}\right)$ and children $\left(5.43 \times 10^{-10} \mathrm{mg}\right.$ TEQ $\left.\mathrm{kg}^{-1} \mathrm{~d}^{-1}\right)$ are much lower than recommended acceptable daily intake. The acceptable risk distribution is equal or lower than $10^{-6}$ for carcinogens and may be up to $10^{-4}$. The observed ILCR $\left(10^{-8}-10^{-5}\right)$ and HQ values less than the acceptable risk level $(\mathrm{HQ}=1)$ (Figure 3 ) suggests minimum risk to the adults and children due to exposure to PCBs through urban soils in Delhi. 


\section{Conclusions}

Low concentrations of PCBs in Delhi soils, and subsequently their intake values, were lower than those established in international guidelines. Therefore, estimates of cancer and non-carcinogenic risk through soil ingestion were low, indicating no harmful effects on the population of Delhi. In future, it may be useful to conduct more intensive assessments for persistent organic pollutants, in response to human health and environmental concerns.

\section{References}

1. ATSDR (Agency for Toxic Substances and Disease Registry). Toxicological profile for polychlorinated biphenyls (update). Atlanta: US Department of Health and Human Services; 2000.

2. Harrad SJ, Sewart AP, Al cock R, Boumphrey R, Burnett V, Duarte-Davidson $\mathrm{R}$, et al. Polychlorinated biphenyls (PCBs) in the British environment: sinks sources and temporal trends. Environ Pollut 1994;85:131-46.

3. Harner T, Kylin H, Bidleman TF, Halshall C, Strachan WMJ, Barrie LA, et al. Polychlorinated naphthalene and coplanar polychlorinated biphenyls in arctic air. Environ Sci Technol 1998;32:3257-65.

4. Loewen MD, Sharma S, Tomy G, Wang F, Bullock P, Wania F. Persistent organic pollutants and mercury in the Himalaya. Aquat Ecosyst Health Manage 2005;8:22333.

5. Park H, Lee SH, Kim M, Kim JH, Lim HS. Polychlorinated biphenyl congeners in soils and lichens from King George Island South Shetland Islands Antarctica. Antarct Sci 2010;22:31-8.

6. Devanathan G, Isobe T, Subramanian A, Asante KA, Natarajan S, Palaniappan P, et al. Contamination status of polychlorinated biphenyls and brominated flame retardants in environmental and biota samples from India. In: Kawaguchi M, Misaki K, Sato H, Yokokawa T, Itai T, Nguyen MT, et al., (eds.). Interdisciplinary studies on environmental chemistry-environmental pollution and ecotoxicology. Tokyo: TERRAPUB; 2012. pp 269-277.

7. Aichner B, Glaser B, Zech W. Polycyclic aromatic hydrocarbons and polychlorinated biphenyls in urban soils from Kathmandu, Nepal. Organic Geochem 2007;38:700-15.

8. Cachada A, Lopes LV, Hursthouse AS, Biasioli M, Grcman H, Otabbong E, et al. The variability of polychlorinated biphenyls levels in urban soils from five
European cities. Environ Pollut 2009;157: 511-8.

9. Wilcke W, Krauss M, Safronov G, Fokin AD, Kaupenjohann M. Polychlorinated biphenyls (PCBs) in soils of the Moscow region: concentrations and small-scale distribution along an urban-rural transect. Environ Pollut 2006;141:327-35.

10. Zhang HB, Luo YM, Wong MH, Zhao QG, Zhang GL. Concentrations and possible sources of polychlorinated biphenyls in the soils of Hong Kong. Geoderma 2007;138: 244-51.

11. Van den Berg M, Birnbaum LS, Michael D, Mike De, William V, Mark F, et al. The 2005 World Health Organization re-evaluation of human and mammalian toxic equivalency factors for dioxins and dioxin-like compounds. Toxicol Sci 2006;93:223-41.

12. Wang DG, Yang M, Jia HL, Zhou L, Li YF. Levels distributions and profiles of polychlorinated biphenyls in surface soils of Dalian, China. Chemosphere 2008;73:3842.

13. Ma WL, Li YF, Sun DZ, Qi H. Polycyclic Aromatic hydrocarbons and polychlorinated biphenyls in topsoils of Harbin, China. Arch Environ Contam Toxicol 2009;57:6708.

14. Kannan K, Ramu K, Kajiwara N, Sinha RK, Tanabe S. Organochlorine pesticides polychlorinated biphenyls and polybrominated diphenyl ethers in Irrawaddy dolphins from India. Arch Environ Contam Toxicol 2005;49:415-20.

15. Zhang G, Chakraborty P, Li J, Sampathkumar P, Balasubramanian T, Kathiresan K, et al. Passive atmospheric sampling of organochlorine pesticides polychlorinated biphenyls and polybrominated diphenyl ethers in urban rural and wetland sites along the coastal length on India. Environ Sci Technol 2008;42:821823.

16. Devanathan G, Subramanian A, Someya M, Sundaryanto A, Isobe T, Takahashi S, et al. Persistent organochlorines in human breast milk from major metropolitan cities in India. Environ. Pollution 2008;157:14854.

17. Kumar B, Kumar S, Gaur R, Goel G, Mishra M, Singh SK, et al. Persistent organochlorine pesticides and polychlorinated biphenyls in intensive agricultural soils from North India. Soil Water Res 2011; 6:190-7.

18. Kumar B, Mishra M, Goel G, Gaur R, Singh SK, Prakash D, et al. Distribution and ecotoxicological risk assessment of persistent organic pollutants (POPs) in river sediments from Delhi, India. Adv Life Sci Technol 2011;1:1-8.

19. Kumar B, Singh SK, Kumar S, Sharma CS. Distribution of polychlorinated biphenyls in surface waters of various sources from National Capital Region Delhi, India. J Natural Sci Res 2012;2:26-38.

20. Kumar B, Singh SK, Mishra M, Kumar S, Sharma CS. Assessment of polychlorinated biphenyls and organochlorine pesticides in water samples from Yamuna River. $\mathrm{J}$ Xenobiotics 2012;2:e6.

21. DoEF (Department of Environment and Forest). State of environment report for Delhi 2010. New Delhi: Department of Environment and Forest - Secretariat; 2010. Available from: http://www.delhi. gov.in/wps/wcm/connect/9e24b08042c3760 2aaafaa6c8168d2a2/SoE+Delhi+2010.pdf? MOD=AJPERES\&CACHEID $=9 \mathrm{e} 24 \mathrm{~b} 08042 \mathrm{c}$ 37602 aaafaa $6 \mathrm{c} 8168 \mathrm{~d} 2 \mathrm{a} 2$

22. USEPA (United States Environmental Protection Agency). Method 3545, Pressurized fluid extraction EPA SW-846. Washington, DC: US Government Printing Office; 1995.

23. Morra P, Bagli S, Spadoni G. The analysis of human health risk with a detailed procedure operating in a GIS environment. Environ Int 2006;32:444-54.

24. USEPA (United States Environmental Protection Agency). Risk assessment guidance for superfund human health evaluation manual (Part A). EPA 540-1-89-002. Washington, DC: United States Environmental Protection Agency; 1989.

25. USEPA (United States Environmental Protection Agency). PCBs: cancer dose-response assessment and application to environmental mixtures. EPA 600 P-96-001F. Washington, DC: United States Environmental Protection Agency; 1996.

26. USEPA (United States Environmental Protection Agency). Regional screening level (RSL): Summary Table: updated 2011. Available from: http://www.epa. gov/region9/superfund/prg/index.html

27. CCME (Canadian Council of Ministers for the Environment). Canadian soil quality guidelines for the protection of environmental and human health, polychlorinated biphenyls (total). Winnipeg, Canada: Canadian Council of Ministers for the Environment; 1999.

28. Shan W, Xia X, Yang Y, Liu H. Distribution source and risk assessment of polychlorinated biphenyls (PCBs) in urban soils of Beijing, China. Chemosphere 2011;82:7328.

29. Wang P, Zhang Q, Wang Y, Wang T, Li X, Li $\mathrm{Y}$, et al. Altitude dependence of polychlorinated biphenyls (PCBs) and polybrominated diphenyl ethers (PBDEs) in surface soil from Tibetan Plateau, China. Chemosphere 2009;76:1498-504.

30. Kishida M, Imamura K, Maeda Y, Lan TTN, Thao NTP, Viet PH. Distribution of persistent organic pollutants and polycyclic aro- 
matic hydrocarbons in sediment samples from Vietnam. J Health Sci 2007;53:291 301.

31. Schmid P, Erika G, Markus Z, Thomas DB, Andre D. Correlation of PCDD/F and PCB concentrations in soil samples from the Swiss soil monitoring network (NABO) to specific parameters of the observation sites. Chemosphere 2005;58:227-34.

32. Dragan D, Simona C, Dirtu A, Mocanu R, Vaeck van L, Covaci A. Occurrence of organochlorine pesticides and polychlorinated biphenyls in soils and sediments from Eastern Romania. Int J Environ Anal Chem 2006;86:833-42.

33. Liu JZJ, Cui H, Xu Y, Tan FX. Dioxin-like polychlorinated biphenyls contamination and distribution in soils from the Modern Yellow River Delta, China. Soil Sediment Contam 2009;18:144-54.

34. Costilla-Salazar R, Trejo-Acevedo A, Rocha-Amador D, Gaspar-Ramirez 0, DiazBarriga F, Perez-Maldonado IN. Assessment of polychlorinated biphenyls and mercury levels in soil and biological samples from San Felipe, Nuevo Mercurio Zacatecas, Mexico. Bull Environ Contam Toxicol 2011;86:212-6.

35. Shelepchikov AA, Brodskii ES, Feshin DB, ZhilNikov VG, Mir-Kadyrova E, Ya Balashova SP. Polychlorinated dibenzo-p- dioxins dibenzofurans and biphenyls in soils of Moscow. Eurasian Soil Sci 2011;44:286-96.

36. Wang Y, Luo CL, Li J, Yin H, Li XD, Zhang G. Characterization and risk assessment of polychlorinated biphenyls in soils and vegetations near an electronic waste recycling site South China. Chemosphere 2011;85:344-50.

37. Salihoglu G, Salihoglu NK, Aksoy E, Tasdemir Y. Spatial and temporal distribution of polychlorinated biphenyl (PCB) concentrations in soils of an industrialized city in Turkey. J Environ Manage 2011;92: 724-32.

38. You H, Ding J, Zhao XS, Li YF, Liu LY, Ma WL, et al. Spatial and seasonal variation of polychlorinated biphenyls in Songhua River, China. Environ Geochem Health 2011;33:291-9.

39. Stockholm Convention. National implementation plans guidance on persistent organic pollutants (POPs), 2012. Châtelaine, Switzerland: Secretariat of the Stockholm Convention; 2012. Available from: http://chm.pops.int/

40. Wevers M, De Fre R, Desmedt M. Effect of backyard burning on dioxin deposition and air concentrations. Chemosphere 2004;54:1351-6.

41. Andersson M, Ottesen RT. Levels of diox- ins and furans in urban surface soil in Trondheim, Norway. Environ Pollut 2008;152:553-8.

42. Park SU, Kim JG, Masunaga S, Kim KS. Source identification and concentration distribution of polychlorinated biphenyls in environmental media around industrial complexes. Bull Environ Contam Toxicol 2009;83:859-64.

43. JECFA (Joint FAO/WHO Expert Committee on Food Additives). Evaluation of certain food additives and contaminants (57th report), 2001. Report Series 909. Geneva: World Health Organization; 2001. pp 13946.

44. European Commission. Amending regulation (EC) No. 466/2001, Setting maximum levels for certain contaminants in foodstuffs as regards dioxins and dioxin-like PCBs, EC No. 199/2006 of 3 February 2006. Official Journal L 32/34, 4/2/2006. Available from: http://eur-lex.europa.eu/LexUriServ/ LexUriServ.do?uri=0J:L:2006:032:0034:00 38:EN:PDF

45. Government of Japan. Dioxin. Tokyo: Office of Dioxins Control, Environmental Management Bureau, Ministry of the Environment, Government of Japan; 2009. Available from: http://www.env.go.jp/en/ chemi/dioxins/brochure2009.pdf 